\title{
Econometric Analysis of Foreign Direct Investment in the Zimbabwean Mining Sector 2005-2014
}

\author{
Plaxedes Gochero \\ Open University of Mauritius, Moka, Mauritius \\ Email: gocheroplaxedes@gmail.com
}

How to cite this paper: Gochero, P. (2018) Econometric Analysis of Foreign Direct Investment in the Zimbabwean Mining Sector 2005-2014. Theoretical Economics Letters, 8, 3157-3177.

https://doi.org/10.4236/tel.2018.814196

Received: June 11, 2018

Accepted: October 23, 2018

Published: October 26, 2018

Copyright $\odot 2018$ by author and Scientific Research Publishing Inc. This work is licensed under the Creative Commons Attribution International License (CC BY 4.0).

http://creativecommons.org/licenses/by/4.0/

\section{(c) (i) Open Access}

\begin{abstract}
The paper analyses the determinants and the effects of foreign direct investment inflows (FDI) in the Zimbabwe Mining Sector (ZMS) in a specific study for 14 minerals from 2005-14 estimating a random effect model. Mineral specific variables examined include capacity utilisation, volume of manufacturing index, labour cost, sectorial contribution to Gross Domestic Product (GDP), political instability, mineral price and mineral output. FDI inflow in the ZMS can be explained by capacity utilisation, volume of manufacturing index, labour, sectorial contribution to GDP and political instability. No statistical evidence could be established to support mineral price and output as major determinants of FDI in the mining sector. All these variables confirmed with literature except for volume of manufacturing index. As a result, the government is recommended to put in place supportive policies that encourage investments and recapitalization in the mining sector so that local firms can effectively compete at both domestic and international investment markets.
\end{abstract}

\section{Keywords}

Foreign Direct Investment Inflow, Zimbabwean Mining Sector

\section{Introduction}

Access to foreign capital and investment enables a country to invest in human and physical capital as well as to make full use of opportunities otherwise not available. Acquisition of capital and making profitable investments is important in the economic improvement of a country. Foreign direct investment is therefore a vital component of development and operation at an international scale. 
Unfortunately, its empirical determinants and effects are not very well understood. Foreign direct investment (FDI) is crucial for developing countries because of the long-term finance, technology, technical knowhow, managerial expertise and marketing experience that if offers. It brings to the host country economic development, and leads to increased employment (Kukaj and Ahmet [1]). Chimuka [2], argued that FDI is crucial in the mining sector for carrying out mineral exploration, extraction, processing and marketing because Zimbabwe lacks enough capital and technological resources to finance such capital intensive large-scale projects. However, negative effects may also flow from FDI; these include increased financial risks, foreign exchange rates crises, transfers of obsolete and dirt technologies. As a consequence one needs to understand not only determinants but also effects of FDI.

A panel data analysis for 14 minerals across a 10-year period (2005-2014) is estimated in a bid to provide answers to the raised questions. Section 2 provides review of the theoretical and empirical literature of this topic. Section 3 shows methodological estimation procedures. Section 4 presents empirical results, discussion and their economic interpretation. Lastly Section 5 gives some possible policy recommendation, as well as suggested areas for future research.

\section{Literature Review}

Various theories have been put forward on the motivations and determinants of FDI. These theories can be divided into macro level theories and micro level theories. However, there is no established theory on the interrelationship between FDI and the mining sector hence it is necessary to consider FDI theories that try to provide an insight into what causes FDI to flow into various investment destination and not just FDI development theories. The eclectic paradigm that is also known as the OLI-Model which is an extension of internalization theory by Dunning [3] will be considered in the theoretical section of the paper because it is more acceptable than the heavily criticised neoclassical condition of perfect competition. The theory argues that the structure of an organisation is not the only significant factor in inviting FDI, but rather three additional elements were added to the theory, and these are Ownership, Location and Internalization advantages. It is a combination of three approaches to FDI, (O-L-I), "O" Ownership advantages, "L" Location and "I" for Internalisation, Denisia [3].

Macroeconomic environment, political stability, FDI incentives, cost of labour, legal framework, availability of resources, level of infrastructural development are some of the factors considered before decisions are made by multinational companies(henceforth MNCs) as far as FDI location is concerned.

The eclectic theory takes into account the significance of three variables namely, country-specific, company-specific and internalisation relating to trade and FDI. The country-specific variables are geographical environment, the political environment, the government's regulatory framework, taxation and fiscal policy, production costs and transportation costs and the cultural environment 
[3]. The specific advantages of each country can be divided into three categories, economic, political and social. The economic benefits consist of quantitative and qualitative factors of production, costs of transport, telecommunications, market size and infrastructure of the host economy, Zimbabwe has a wide range of these services however not much FDI has been attracted yet.

Internalisation, being another characteristic of the eclectic paradigm offers a framework for assessing different ways in which the company will exploit its powers from the sale of goods and services to various agreements that might be signed between the companies. The higher the cross-border market internalisation benefits the more the firm will want to engage in foreign production rather than offering this right under license, franchise. Eclectic paradigm OLI shows that OLI parameters are different from company to company and depend on context and reflects the economic, political, social characteristics of the host country. Therefore the objectives and strategies of the firms, the magnitude and pattern of production will depend on the challenges and opportunities offered by different types of countries. The main challenge in Zimbabwe can be argued to have been political and partly economical; this fact might have made the economy a less safe FDI destination although it provides all other advantages posed by the theory.

This scenario encourages the current study to assess the determinants of FDI, macroeconomic policy, political stability, and cost of labor, legal framework guiding FDI, availability of resources, FDI incentives and level of infrastructural developed to find out how they affect or influence the flow of FDI in the Zimbabwe mining sector. The study will test the theories of FDI effect on economic growth which have remained ambiguous in previous studies with the aim of shedding more light on this controversial topic. The study seeks to provide answers to the question of whether the mining sector should continue seeking or abandon the search for FDI. Economic development in the mining sector contributes to the economic development of the whole country and therefore the current research could help clear up the gray areas raised by previous researchers.

Empirical studies on both macro and/or micro data are yet to reach consensus on both the determinants and effects of FDI on the performances of either a particular sector or economy in general. Few studies on Africa have attempted either to establish determinants of FDI on a particular sector of the economy. Most of the available literature is on FDI and economic growth at large.

There are differing findings about the actual impact of political stability on FDI inflows. Demirhan and Masca [4], studied FDI inflows in developing countries between 2000 and 2004 they came up with the conclusion that political risk has an insignificant effect on FDI. The argument was that investors were concerned with returns rather than political risks. Opposite results are held by Luiz and Ruplal [5], who argued that security of tenure; political stability and the availability of infrastructure were the most important factors influencing the internationalisation of South African mining firms. It is apparent from these stu- 
dies that political stability increases the probability of attracting more FDI inflows in a nation's particular sector thus political stability is expected to have a positive effect on FDI inflows. Contrary to recent studies Tsikata et al. [6], could not confirm that political instability was a significant determinant of FDI, Anyanwu [7] [8], Moyo [9], Kariuki [10], later confirmed it as a prime variable. Divergent results need to further study the Zimbabwean mining sector as the developing country argument is contrary to the single nation argument. The argument is not the effect but rather the significance of the factors in influencing FDI.

Severiano's [11], study, "The determinants of FDI in Portugal," concluded that most foreign investing firms do not choose to invest in Portugal to take advantage of a cheap labour force. According to Severiano [11], a raise in the real minimum wage was found to affect positively FDI inflows. This is very interesting because previous research by different scholars indicated that FDI favours countries with low labour costs, see for example, Mody and Srinivasan [12]. Recent research by Bayraktar-Saglam and Böke [13], however, examined the endogenous interaction between labour costs and Foreign Direct Investment (FDI) in the OECD countries via the Panel VAR approach under system GMM estimates for the period 1995-2009. The empirical findings revealed that sactorial composition of FDI and the decomposition of labour costs play a significant role in investigating the dynamic association between labour costs and FDI. It will be interesting to find out how labour cost determines FDI inflows to Zimbabwe.

Having discussed much about the determinants of FDI it becomes imperative to review the effect of FDI. Rate of growth can be explained by the state of technology used by a country [14]. However, on the state of technology it may be necessary to concentrate on sectorial level rather than at national level so as to have a clear understanding of its effects. Transfer of technology and knowledge by MNCs through FDI increases and improves productivity which leads to growth of Gross Domestic Product argue Varamini, and Vu [15]. Contrary to this view, MNCs could bring obsolete and dirty technology [16].

Aswal [17] argues that host countries are integrated into the global economy thanks to financial flows received from FDI and that there is a link between the increase of FDI and rapid integration into global trade. However, further integration into the global economy can bring negative effects. Since FDI has a greater impact on imports than on exports this influences negatively the balance of payment which might prompt capital flight and repel FDI in the long run. FDI is the easiest way of spreading economic problems in the world especially those that have occurred in the MNCs countries of origin; for example, -host countries are forced to open economies and are more subject to global changes than would be the case, Khurtishi-Kastrati [18].

Furthermore, FDI can be cardinal in producing a better economic environment resulting in economic growth: as Honsen and Rand [19], argued FDI is a source of change. FDI can create entry barriers and or it can eliminate or reduce monopolies in these sectors changing the structure of the local economy for the 
best or worst. By takeovers and privatization MNCs force the adoption of their policies and procedures. These arguments have not only highlighted that the effects of FDI on the sector are inconclusive but even that the effects on the structure of the economy are not conclusive.

Using the OLS method of estimation Adewuni [20], Anyanwu [7], and Moyo, [9], studied the possible impact of FDI on economic growth. Of these studies, Moyo [9], made an attempt to establish the determinants of FDI in the post dollarization period of 2009 to 2012 in Zimbabwe using monthly data. The study established a positive relationship in respect to FDI. It should also be noted that Moyo [9], study was based only on macro data. That data was based on the whole nation and not on sectors, which is instead the scope of this study. Adewuni [20], employing a pooled OLS had a similar objective for nine African countries and concluded that economic growth was insignificant as a determinant of FDI. Anyanwu [7], focused on the Nigerian economy for a 27-year period [1980-2007], and share the same results with Adewuni [20], in the sense that economic growth was irrelevant in attracting FDI but rather he found natural resource endowment and exploitation especially for oil as the prime determinants of FDI. Since Nigeria is highly endowed with oil which was found to be a determinant for FDI, this study seeks to find out if such a conclusion could be reached on the diamond sector and FDI in Zimbabwe given the fact that the country is highly endowed with the germ.

Oluwatosin [21], examined the causal linkages between FDI and economic growth and financial development in 5 African nations that is Gambia, Ghana, Ivory Coast, Nigeria and Sierra Leone from 1970-2005. A Vector Error Correction Model (VECM) was employed in the trivariate framework and results showed FDI to have bi directional causality on both financial and economic growth while financial development had a causal relation on economic growth and not the other way. A similar estimation concept was employed by Javorvick [22], on firm-based panel of 9 MNCs. The focus was to test for productivity spillovers from FDI that would result from linkages between foreign and domestic suppliers and forward linkages (interactions between foreign suppliers of intermediate inputs and their domestic customers). This sort of methodology can also be employed to establish the relationship between mining sector performance and FDI. Given the size of the sector with 14 main minerals, a mineral based panel may also yield superior results to secondary macro data.

In a separate all Africa's FDI determinant study done by Anyanwu [8], for which data from 1996-2008 was studied for those nations in a pooled ordinary squares and Fixed General Least Square estimation technique was employed. Results showed market size and trade openness to be the most (positive) significant factor in attracting FDI. However financial market development was found to have a negative impact while economic growth had no share on attracting FDI.

In a study by Kariuki [10], an estimated Least Square Dummy Variable also known as the fixed effects model for a sample of 35 African countries including 
Zimbabwe was used and produced similar results to those found by Anyanwu [8]. The only difference was that financial sector development this time around was found to have a positive effect on FDI attraction for the nation. One would wonder if the use of a different methodology would influence the results or if it is the sample size that affects variable significance. It is not only Anyanwu [8], who could not establish the significance of the economic growth similar results were obtained even by Adewuni [20].

In terms of determinants and effects of FDI on mining sector nothing much can be drawn from the reviewed literature as most studies focused on either or both determinants and effect of FDI on economic growth. Interestingly, of that existing literature contradictory views on the link between FDI and economic growth were found. Hence, this study does not only seek to contribute to that debate but to empirically establish determinants and effects of FDI in the Zimbabwean mining sector context.

\section{Methodology}

Theory and empirical studies carried out by previous scholars provide a foundation for model building. Approach and methods to be used in this research are explained in this section. The approach and methods of this study relates to studies by Javorvick [22] and Oluwatosin [21]. This study presents results from panel data regressions from 14 minerals for the period 2005 to 2014. The suitable model to study determinants and effects is the one expressed by an analytical approach similar to that used by Javorvick [22], Oluwatosin [21], with the needed ad hoc adjustments model is:

$$
\begin{gathered}
F D I_{i, t}=\alpha+\beta X_{i, t}+\varepsilon_{t} \\
X_{i, t}=\beta_{0}+D P S_{i, t}+\beta_{2} V M I_{i, t}+\beta_{3} \operatorname{COST}_{i, t}+\beta_{4} \operatorname{PRICE}_{i, t}+\beta_{5} C U_{i, t} \\
+\beta_{6} \text { CONTR }_{i, t}+\beta_{7} O U T_{i, t}+\beta_{7} L A B R+\mu_{i, t} \\
D= \begin{cases}1 & 2005-8,2013 \\
0 & \text { otherwise }\end{cases}
\end{gathered}
$$

where $F D I$ is the foreign direct investment inflow in a particular mineral, $X$ is a set of all possible factors that determine $F D I$ inflow into a firm and $t$ is annual time period from 2005 to 2014 for 14 minerals. While $\alpha$ and $\beta$ are related coefficients and $\varepsilon_{t}$ is a vector of white noise disturbance.

The study wants to establish through estimation the determinants and effects of FDI on the mining sector performance of the Zimbabwean economy.

\subsection{Panel Data Analysis}

Panel data analysis is a frequently used approach in FDI and growth research since it enables the researcher to study the dynamics of the change of economic growth per capita for a short time series [2005-2014]. Since panel data combines both cross-sections and time series it can enhance the quality of data and sort out economic effects that cannot be distinct with only cross-sections or time se- 
ries data. Panel data also has more numbers of data points that generate additional degrees of freedom which improve the efficiency of the econometric estimates. Moreover, using information of both temporal (time) and minerals (cross-section) effects one can substantially overcome omitted or missing variables problem [23]. Some models that can be used for panel data analysis are described below.

\subsection{Constant Coefficient Model}

$$
F D I_{j, t}=a+\beta_{i} X_{j, t}+\varepsilon_{j, t},
$$

$j=1, \cdots 14, j$ is for minerals; $t=1 \cdots 10$, for $2005=1$.

The constant intercept assumption means that all minerals are considered to be the same and there are no significant cross sectional and time specific effects. The first step here is simply combining both the time-series and cross-section data, also known as pooling, and then estimating parameters with ordinary least squares (OLS). This simple use of pooled data enables the testing of theories and assumptions with relative ease. The estimated parameters of this model will be used as a benchmark against other estimates from the more sophisticated models.

By ignoring the cross section and time specific effects that possibly exist, the parameters estimated will be meaningless and inconsistent. To account for possible heterogeneity among minerals, fixed effects models and random effects models are considered to be more appropriate for handling panel data.

Hsiao [23] argued that it makes no difference whether fixed or random effect models are used when $\mathrm{T}$ (time series) is large, but if $\mathrm{T}$ is finite and $\mathrm{N}$ is large it could make a surprisingly difference in the estimates. Since the data set of this study only consist of 10 years for each of the 14 minerals, it is essential to choose the correct model to make the best use of this small amount of information. Hsiao [23] argued that one way to decide to use fixed effects or random effects model is to test for misspecification of the random effects model, where $a$ is assumed to be random and uncorrelated with the independent variables.

To test the significant hypothesis, this study will perform a Hausman-test which tests for correlated random effects. If $a$ is uncorrelated with the independent variables and thus the null hypothesis holds then a random effects model should be applied. Contrary, if the alternative hypothesis holds, a fixed effect model should be applied. The Hausman-test suggests the null hypothesis may not be rejected if, P-value $>$ critical value mostly 0.05 thus it will be possible to use cross-section random effects estimators.

\subsection{Definition and Justification of Variables}

The determinant variables of FDI inflows include macroeconomic policy, political stability, mineral price, cost of labour, mineral output, volume of manufacturing index and sectorial contribution to economic growth. These variables are interrelated and are derived from the eclectic theory by Dunning [3]. 
Foreign direct investment inflow (FDI) constitutes a direct capital investment for the purpose of development and enterprising in a foreign country by TNCS. Such investment is very useful in developing countries especially when channeled to a nation's industries such as mining. For enterprises on Zimbabwe Stock Exchange such activities are not considered FDI but rather transfer payment. FDI in the mining sector like Output in the very sector will be considered on annual bases and the variable is also considered to be a dependent variablehence no prior exception to talk about, Henry [24], Javorvick [22] and Oluwato$\sin [21]$.

Political stability (PS) is cardinal for normal macroeconomic and business environment in a nation [5] [25]. Political risk refers to activities that interrupt business or harm staff and property for example property take over by government and violent demonstrations. These factors influence the decision to invest or not to invest in a certain location Dunning [25]. All the above will be considered as proxy for political stability. Political stability increases the probability of attracting more FDI inflows into nation.

Cost of labour (COST) is the total amount of expenditures on labour force, cost of labour is considered as a percentage of income in that particular year. Henry [24], Javorvick [22], and Oluwatosin [21] argued that cost of labor theories are important for FDI as investors look for countries with lower labor costs so as to maximize profits. Thus we would expect cost of labour to negatively influence FDI inflows in a firm.

Output (OUT) is the real output of each mineral produced annually and this would be introduced to capture the total output of economic activities in the firm, This variable is also used as the income level, which is considered as the main resource of technological development and human capital improvement. Investors would also consider this variable especially as percentage of total sector output so as to measure the potential market size when deciding FDI location, especially those who target to enhance their market share in the host country. All the extracting mining firms in the economy are viewed to constitute Zimbabwe Mining Sector (ZMS).

Price-PRICE is the closing year International price of the mineral understudy. This variable is used to test the impact of mineral prices in a small economy such as Zimbabwe and it would be expected that this variable would influence the attraction of FDI. Adewuni [20], and Anyanwu, [7], have all included the mineral price in their study of determinants of FDI in a particular sector or for that particular resource.

Capacity utilisation- $C U$ is the measure of operational capacity for minerals by the mining firms and it would be expected to impact positively on direction of foreign direct investment inflows. However, there might be a possibility of reserve effect which is beyond the scope of the study. The variable was once used by Ramirez [26], Anyanwu [8], and Fasanya [27].

Volume of the Manufacturing Index-( $V M I)$ is considered the proxy for rate of growth of mining sector as the index measure for mineral and quarry activities 
only. This variable provides an indication on the possible effect of the sectorial activities on its ability to influence the direction of flow of FDI in that particular sector. Hermes and Lensink [28], Varamini, and $\mathrm{Vu}$ [15], Volume of the Manufacturing Index-( VMI) is considered the proxy for rate of growth of mining sector as the index measure for mineral and quarry activities only. This variable provides an indication on the possible effect of the sectorial activities on its ability to influence the direction of flow of FDI in that particular sector. Hermes and Lensink [28], Buckley, et al. [29], Ikechi, et al. [30], Orji, et al. [31], are among those who have used this variable.

Contribution to GDP-(CONTR), Oladipo [32], Fasanya [27], and Anyanwu [8], Moyo [9] all argued that contribution of a particular sector has a role to play in influencing the direction of the flow of FDI in that particular sector. They all agreed that the variable positively help to attract FDI hence; a positive coefficient on the variable is expected. This will be measured as the percentage contribution of the mining sector to the country's GDP.

\section{Estimated Results}

\subsection{F-Test (Pool Ability Test)}

In a bid to find the most suitable model between the fixed effects model and the pooled OLS model pool ability tests were carried out. The hypothesis to be tested is that there is no mineral specific heterogeneity i.e. the pooled OLS model is the most suitable against the alternative that the fixed effect is the proper model. The F-test results ${ }^{1}$ reject the null hypothesis, implying that there is mineral specific heterogeneity, thus the pooled OLS model is not the appropriate model of the two.

\subsection{Breusch and Pagan Lagrange Multiplier Test for Random Effects (LM)}

To determine the most suitable model between the random effects and the pooled OLS model a LM test was carried out. Results ${ }^{2}$ failed to accept the null hypothesis and it can be concluded that there are panel effects. Thus the pooled OLS model is not to be preferred over the random effects model.

\subsection{Hausman Test}

The Hausman test $t^{3}$ was carried out to determine the best model between the fixed effects model and the random effects model. It was necessary to test hypothesis that there is no relationship between mineral specific heterogeneity and the explanatory variables i.e. the random effects model is the appropriate model against the alternative hypothesis that the fixed effects is the appropriate model. The null hypothesis could not be rejected and therefore the conclusion is that the random effects is the best model.

${ }^{1}$ Annual bases for each firm in the firm panel model and FDI is a depended variable. ${ }^{2}$ See appendix for the Breusch and Pagan Lagrange multiplier test for random effect results. ${ }^{3}$ See appendix for the Hausman test results. 


\subsection{Heteroskedasticity Test}

The Breusch-Pagan/Cook-Weisberg test for heteroskedasticity ${ }^{4}$ was conducted to verify the nature of the variances of the error terms, that is, are they homoscedastic or not? It was decided to reject the null hypothesis and conclude that there is statistical evidence of heteroskedasticity. However, as noted in Mulenga [33], this problem can be easily dealt with by estimating a feasible generalized least square (FGLS) in the random effects model.

\subsection{Estimation of the Model}

\subsubsection{The Unrestricted Random Effects Model (REM)}

The various econometric tests conducted concluded that the REM is the most appropriate model for estimating the mineral specific determinants of FDI in the mining sector. A Generalized Least Squares (GLS) regression of the unrestricted REM was run. The results found all other variables significant at the conventional levels of significance (1\%,5\% and 10\%) except for price and costs. It was therefore decided to drop these variables one by one, starting with price as it was the variable that was highly insignificant. Subsequently cost was dropped and another regression was run.

\subsubsection{Presentation of the Restricted REM Results}

Tables 1-3 are a summary of the REM results after elimination of insignificant variables of the unrestricted model. The explanatory variable of the restricted model are all significant at either the $1 \%, 5 \%$ or $10 \%$ level of significance.

Random-effects (GLS), using 140 observations;

Included 14 cross-sectional units;

Time-series length $=10$;

Dependent variable: L_FDI;

"These cross-sectional units were the results of REM using Stata. There were 140 observations for the 14 minerals. The regression covered 10 years."

There were 140 observations obtained from pooling time series data from 14 minerals each contributing 10 observations as reported in the table above. The regression results report a Wald chi 2(5) statistic of 21.03, with a p-value of 0.008 . This implies that there is statistical evidence that at least one of the regression coefficients is statistically different from zero. The reported Hausman test further supports the argument early raised that random effect model is the best one and its estimates are consistent.

\subsection{Capacity Utilisation (CU)}

The variable $C U$ is found to be significant at $5 \%$ level with the expected positive sign. The results confirm the findings of many other studies done on the country specific determinants of foreign direct investment inflows. For instance, Ramirez [26], Anyanwu [8] and Fasanya [27] all found a positive value for the CU variable with respect to FDI. A positive coefficient of 0.0224 implies that a $1 \%$ ${ }^{4}$ See appendix. 
Table 1. REM results.

\begin{tabular}{cccccc}
\hline & Coefficient & Std. Error & t-ratio & p-value & \\
\hline CONST & 8.59821 & 1.44097 & 5.9670 & $<0.0001$ & $* * *$ \\
$P S$ & -1.02268 & 0.185225 & -5.5213 & $<0.0001$ & $* * *$ \\
L_LABR & 0.463614 & 0.207414 & 2.2352 & 0.0271 & $* *$ \\
$V M I$ & -0.0407823 & 0.00778521 & -5.2384 & $<0.0001$ & $* * *$ \\
$C U$ & 0.0224109 & 0.00939814 & 2.3846 & 0.0185 & $* *$ \\
$C O N T R$ & 0.347487 & 0.0217281 & 15.9925 & $<0.0001$ & $* * *$ \\
\hline
\end{tabular}

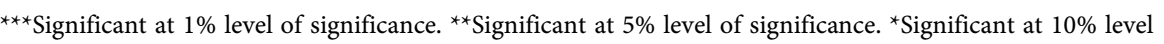
of significance. Source: Created by author.

Table 2. Breusch-Pagan test.

Null hypothesis: Variance of the unit-specific error $=0$

Asymptotic test statistic: Chi-square $(1)=392.6$ with p-value $=2.2478 \mathrm{e}-087$

Source: Created by author.

Table 3. Hausman test.

$\frac{\text { Null hypothesis: GLS estimates are consistent }}{\text { Asymptotic test statistic: Chi-square }(5)=0.71204 \text { with p-value }=0.982301}$

Source: Created by author.

increase in the capacity utilisation in the mining sector will result in an increase in FDI inflows share by approximately $2.24 \%$ holding everything else constant. The results confirm that the economic size of the mining sector is very important for the attraction of FDI inflow in that particular sector. The larger the sector the bigger the markets power, this fosters innovativeness amongst investors as they try to secure more of the input so as to differentiate their final products from their competitors. According to Krugman [34], through product differentiation, firms can concentrate on a limited set of products, this result in lower per unit cost as firms exploit economies of scale. Hence increase in capacity utilisation has positive effect in attracting FDI inflows in the Zimbabwe's mining sector.

\subsection{Contribution of the Mining Sector (CONTR)}

The variable is highly significant at $1 \%$ level with the expected positive sign. The coefficient of 0.347 implies that for a $1 \%$ increase in the contribution of the mining sector to the economies GDP leads to 34.47 percentage increase in FDI inflows in the mining sector. The results confirm economic theory, as it is expected that the more the sector grows the more it can attract investments. Anyanwu [8], Fasanya [27] and Oladipo [32] all get of similar results for different nations and sectors while they agree that contribution of sector influence FDI inflows in that particular sector. 


\subsection{Volume of Manufacturing Index (VMI)}

The variable $V M I$ is found to be highly significant at $1 \%$ with an unexpected negative sign. The negative coefficient of 0.04078 implies that a $1 \%$ increase in the $V M I$ will result in a decrease in FDI in the mining sector share by approximately $4.08 \%$, holding everything else constant. Orji, et al. [31], results were that FDI has a negative correlation with manufacturing output. Ikechi, et al. [30], study established that Nigerian industrial productivity is not dependent on FDI, however, when individual component sectors were examined the findings were that FDI has a positive and significant relationship with mining sector productivity in Nigeria at $5 \%$ level in the short term. The results, though not conforming to economic theory, could be justified on the grounds that Zimbabwe for the large part of the period understudy experienced economic decline. Thus it can be concluded that economic decline negatively affects FDI inflow in the ZMS.

\subsection{Labour ( $L A B R)$}

The variable was found to have the expected positive sign and statistically significant at 5\% level. The coefficient of 0.4636 implies FDI inflows in the mining sector are relatively elastic to changes in labour level available to the sector and mineral specific. Thus a unit percentage increase in Labour will result in 46.36 percentage increase in FDI inflows in the ZMS. Thus a unit percentage increase in Labour will result in 46.36 percentage increase in FDI inflows in the ZMS. The findings are similar to those held by Henry [24], Demirhan and Masca [4], Hussain and Kimuli [35]. These findings lead to the conclusion that Labour levels availability has been positively affecting and influencing FDI inflow in the Zimbabwe Mining Sector for the period under study.

\subsection{Political Stability (PS)}

Dummy variable for political instability is highly significant at $1 \%$ level of significance. The variable has the expected negative sign and the coefficient of 1.02268 implies that political instability negatively affects the FDI inflows in the Zimbabwe's mining sector by 63.037 percentage. Similar results are held by Demirhan and Masca [4], and Luiz and Ruplal [5] for the different nations they studied.

\section{Conclusions}

Comparative results of the three models: the pooled OLS (POLS), random effects model (REM) and the fixed effects model (FEM), show that the REM and POLS report results which are comparably similar in terms of the coefficients and expected signs. However, $\mathrm{CU}$ was also significant but the coefficient of this variable for the FEM differs significantly from those of the POLS and the REM. Legislators have well vested interest in implementing policies aimed at stabilisation and efficiency in the Mining sector. For one to formulate an effective policy that 
strikes a balance between the two, one needs to understand the determinants of FDI so as to adopt policies that promote a sustainable and stable Mining sector for economic growth.

The study finds that mining firms can increase FDI inflows by a small percentage increase in capacity utilisation. Hence there is a call for mining firm managers to be innovative and incorporate information and communications technology when dealing with mineral products.

It is thus recommended that government should put in place supportive policies that encourage investments and recapitalization of the mining sector so that local commodity can effectively compete both on the domestic and international markets. This could involve provision of a relative stable political environment which boosts investor confidence and thus helps attract foreign direct investments. Furthermore, government should put in place an enabling environment with enough incentives to spur innovativeness amongst local mineral mining firms, so that different varieties of products appealing to different sections of consumers both domestically and internationally are readily available.

As is noted in the Chamber of Mines annual reports [36], most companies are operating below full capacity owing to challenges related to working capital, inadequate provision of supportive infrastructure (energy, water), obsolete equipment and low consumer demand. The Zimtrade export capacity mining survey of 2011 noted a decline in companies exporting; thus there is need for government to pursue a rigorous export led industrialization strategy following in the footsteps of the Asian tigers. However, it is imperative to put place an enabling policy environment which recognizes need to tap in foreign direct investments, protect property rights and uproot corruption.

From the results, labour was found to be a significant explanatory variable for FDI inflow in the ZMS. It is thus recommended that government should undertake policies which nurture and support growth of labour to the sector. This would require the government to establish a menu of policies that reinforces confidence amongst domestic and foreign investors, spruces the image of Zimbabwe as a prudent borrower and above all, fosters the development and retention of human capital. Due to data limitations, the study concentrated on 14 out of 66 minerals to draw conclusions on the mineral specific determinants of FDI in the country's mining sector. A richer data set would broaden this study to include other important minerals in the sector, such as diamond. Furthermore, the scope of the study was limited to investigating the sector mineral specific determinants of FDI and this could be extended to incorporate company specific determinants of FDI; for instance the analysis could be enriched adding the capital to labour ratios and proxies for productivity.

\section{Conflicts of Interest}

The author declares no conflicts of interest regarding the publication of this paper. 


\section{References}

[1] Kukaj, H. and Ahmeti, F.B. (2016) The Importance of Foreign Direct Investments in Economic Development in Transitional Countries: A Case Study of Kosovo. European Scientific Institute, ESI.

[2] Chimuka, L. (2007) Murowa Kimberlite Field: University of Zimbabwe Summer Symposium. University of Zimbabwe Publications, Harare.

[3] Dunning, J.H. (1988) The Eclectic Paradigm of International Production: A Restatement and Some Possible Extensions. Journal of International Business Studies, 19, 1-31.

[4] Demirhan, E. and Masca, M. (2008) Determinants of Foreign Direct Investment Flows to Developing Countries: A Cross-Sectional Analysis. Prague Economic Papers, 17, 356-369. https://doi.org/10.18267/j.pep.337

[5] Luiz, J. and Ruplal, M. (2010) Working Paper, 194. Wits Business School, University of Witwatersrand.

[6] Tsikita, G.K., Asante, Y. and Gyasi, E.M. (2000) Determinants of Foreign Direct Investment in Ghana. Overseas Development Institute.

[7] Anyanwu, J.C. (2011) Determinants of Foreign Direct Investment Inflows to Africa, 1980-2007. African Development Bank Group.

[8] Anyanwu, J. (2012) Why Does Foreign Direct Investment Go Where It Goes? New Evidence from African Countries. Annals of Economic Finance, 13, 425-462.

[9] Moyo, T. (2013) The Impact of Foreign Direct Investment on Economic Growth: The Case of Zimbabwe 2009-2012. International Journal of Economics, Finance and Management Sciences, 1, 323-329.

[10] Kariuki, C. (2015) The Determinants of Foreign Direct Investment in the African Union. Journal of Economics, Business and Management, 3, 346-351.

[11] Andreia Alexandra Faria Severiano (2011) The Determinants of FDI in Portugal-A Sectoral Approach. https://www.iseg.ulisboa.pt/aquila/getFile.do?method=getFile\&fileId=503913

[12] Mody, A. and Srinivasan, K. (1998) U.S. and Japanese Investors: Do the March to the Same Tune? Canadian Journal of Economics, 31, 778-799. https://doi.org/10.2307/136491

[13] Bayraktar-Sağlam, B. and Selin Sayek Böke, S.S. (2017) Labor Costs and Foreign Direct Investment: A Panel VAR Approach. MDPI, Open Access Journal, 5, 1-23.

[14] Lim, E. (2001) Determinants of, and the Relation between, Foreign Direct Investment and Growth: A Summary of the Recent Literature. International Monetary Fund Working Paper, Middle Eastern Department.

[15] Varamini, H. and Vu, A. (2007) Foreign Direct Investment in Vietnam and Its Impact on Economic Growth. International Journal of Business Research, 7, 132-139. http://www.etsg.org/ETSG2009/papers/forte.pdf

[16] Djokoto, J.G. and Dzeha, G.C. (2012) Determinants and Effects of Foreign Direct Investment in Ghana-Review of Literature. The International Institute for Science, Technology and Education, 2, 25-35.

[17] Aswal, N. (2014) China's Integration into Global Trading System and Its Implications for India. Doctoral Thesis.

[18] Khurtish-Kastrati, S. (2013) The Effects of Foreign Direct Investments for HostCountry's Economy. European Journal of Interdisciplinary Studies, 5, 26-38.

[19] Hansen, H. and Rand, J. (2006) On the Causal Links between FDI and Growth in 
Developing Countries. World Economy, 29, 21-41. https://doi.org/10.1111/j.1467-9701.2006.00756.x

[20] Adewuni, S. (2006) The Impact of FDI on Growth in Developing Countries: An African Experience 1970-2003. Jonkoping International Business School, Sweden.

[21] Oluwatocin, A., Olusegun, O., Festus, O.E. and Abibola, O. (2012) Foreign Direct Investment, Economic Growth and Financial Sector Development in Small Open Developing Economies. Economic Analysis and Policy, 42, 105-127. https://doi.org/10.1016/S0313-5926(12)50008-1

[22] Javorvick, B. (2004) Does Foreign Direct Investment Increase the Productivity of Domestic Firms? In Search of Spillovers through Backwards Linkages. American Economic Review, 94, 605-627. https://doi.org/10.1257/0002828041464605

[23] Hsiao, C. (1986) Analysis of Panel Data, Vol. 11 of Econometric Society Monographs. Cambridge University Press, New York.

[24] Henry, J.F. (2000) Adam Smith and the Theory of Value. Department of Economics, California State University, Sacramento.

[25] Dunning, J.H. (1993) Multinational Enterprise in the Global Economy. Addison Wesley Publishing Co., Wokingham.

[26] Ramirez, M. (2010) Economic and Institutional Determinants of FDI Flows to Latin America: A Panel Study. Trinity College, Department of Economics.

[27] Fasanya, I. (2012) Capital Flows-Growth Nexus in Nigeria: Has Foreign Direct Investment Played a Role in Accelerating Economic Growth? Journal of Sustainable Development in Africa, 14, 34-52.

[28] Hermes, N. and Lensink, R. (2003) FDI, Financial Development and Economic Growth. Journal of Development Studies, 40, 142-163. https://doi.org/10.1080/00220380412331293707

[29] Buckley, P.J., Clegg, J. and Zheng, P. (2007) The Impact of Foreign Direct Investment on the Productivity of China's Automotive Industry. Management International Review, 47, 707. https://doi.org/10.1007/s11575-007-0041-1

[30] Ikechi, K.S., Emmanuel, N.C., Onyechere, P.O. and Sussan, O.A. (2017) Foreign Direct Investments and Industrial Productivity in Nigeria. Journal of Economics and Sustainable Development, 8, 162-180.

[31] Orji, A., Antoner-Orji, O.I., Nchege, J.E. and Okarfor, J. (2015) Manufacturing Output and Foreign Direct Investment in Nigeria: A New Evidence. International Journal of Academic Research in Economics and Management Sciences, 4, 16-28.

[32] Oladipo, O.S. (2010) Foreign Direct Investment (FDI): Determinants and Growth Effects in a Small Open Economy. The International Journal of Business and Finance Research, 4, 75-88.

[33] Mulenga, M.C. (2012) An Investigation of the Determinants of Intra-Industry Trade between Zambia and Its Trading Partners in the Southern African Development Community (SADC). TIPS Working Paper Series.

[34] Krugman, P. and Obstfeld, M. (2009) International Economics: Theory and Policy. 8th Edition, Pearson Addison Wesley, Boston.

[35] Hussain, F. and Kimuli, C.K. (2012) Determinants of Foreign Direct Investment Flows to Developing Countries. SBP Research Bulletin, 8, 13-31.

[36] Chamber of Mines Annual Reports $(2012,2013)$ Harare. 


\section{Appendix 1}

\section{The Sample}

The sample was made up of the following minerals, asbestos, chrome, coal, cobalt, copper, gold, graphite, iridium, nickel, palladium, phosphate, platinum, rhodium, and rhithium. The original mineral data obtained from Zimbabwe National Statistical Agency, (ZIMSTAT) is attached.

Table A1. Raw data.

\begin{tabular}{|c|c|c|c|c|c|c|c|c|c|c|}
\hline & FDI & OUT & PRICE & $\mathrm{vmi}$ & $\mathrm{cu}$ & contr & labr & PS & CRS ID & TIMEID \\
\hline ASB 1 & $133,823.748$ & 6554.601 & 542.647692 & 56.7266 & 56 & 4 & 2154.993956 & 0 & 1 & 2005 \\
\hline ASB 2 & $1,581,273.712$ & 6665.27 & 197.681078 & 49.176 & 54 & 6 & 1841.0648 & 0 & 1 & 2006 \\
\hline ASB 3 & $615,281.6$ & 4629.03 & 4.729899261 & 46.1896 & 40 & 8 & 1815.0138 & 0 & 1 & 2007 \\
\hline ASB 4 & $1,059,822.556$ & 3571.84 & 173.69 & 34.0332 & 34 & 6 & 1845.8448 & 0 & 1 & 2008 \\
\hline ASB 5 & $793,713.264$ & 4970.81 & 315.3003112 & 31.9186 & 41 & 8 & 1973.4708 & 1 & 1 & 2009 \\
\hline ASB 6 & $1,615,114.2$ & 2030.97 & 644.416855 & 41.2271 & 51 & 12 & 2246.1698 & 1 & 1 & 2010 \\
\hline ASB 7 & $2,551,880.436$ & 0 & 366.846 & 65.3027 & 55 & 13 & 2649.4584 & 1 & 1 & 2011 \\
\hline ASB 8 & $5,952,849.48$ & 0 & 798.3050847 & 53.1 & 60 & 15 & 2421.309 & 1 & 1 & 2012 \\
\hline ASB 9 & $6,145,124.98$ & 377 & 834.3928827 & 62.8539 & 58 & 15.7 & 2450.228 & 1 & 1 & 2013 \\
\hline ASB 10 & $6,152,816$ & 0 & $2.17554 \mathrm{E}-09$ & 63.2565 & 60 & 16.9 & 2152.3862 & 1 & 1 & 2014 \\
\hline CHR 1 & $273,246.816$ & 544.3882 & 142.0722286 & 56.7266 & 56 & 4 & 4400.155022 & 0 & 2 & 2005 \\
\hline CHR 2 & $3,228,709.504$ & 519.604 & 87.25352983 & 49.176 & 54 & 6 & 3759.1616 & 0 & 2 & 2006 \\
\hline CHR 3 & $1,256,307.2$ & 398.3646084 & 786.768321 & 46.1896 & 40 & 8 & 3705.9696 & 0 & 2 & 2007 \\
\hline CHR 4 & $2,163,989.152$ & 253.99 & 197 & 34.0332 & 34 & 6 & 3768.9216 & 0 & 2 & 2008 \\
\hline CHR 5 & $1,620,636.288$ & $193,673.74$ & 94.87971142 & 31.9186 & 41 & 8 & 4029.5136 & 1 & 2 & 2009 \\
\hline CHR 6 & $3,297,806.4$ & $516,776.08$ & 110.0619262 & 41.2271 & 51 & 12 & 4586.3216 & 1 & 2 & 2010 \\
\hline CHR 7 & $5,210,534.112$ & $599,079.38$ & 250.99 & 65.3027 & 55 & 13 & 5409.7728 & 1 & 2 & 2011 \\
\hline CHR 8 & $12,154,772.16$ & $408,475.81$ & 119.8797011 & 53.1 & 60 & 15 & 4943.928 & 1 & 2 & 2012 \\
\hline CHR 9 & $12,547,368.16$ & 355,142 & 102.5436924 & 62.8539 & 58 & 15.7 & 5002.976 & 1 & 2 & 2013 \\
\hline CHR 10 & $12,563,072$ & 408,422 & $4.7778 \mathrm{E}-11$ & 63.2565 & 60 & 16.9 & 4394.8304 & 1 & 2 & 2014 \\
\hline COAL 1 & 8398.98 & 8638.65 & 25.35583755 & 56.7266 & 56 & 4 & 135.2506667 & 0 & 3 & 2005 \\
\hline COAL 2 & $99,243.12$ & $10,826.55914$ & 22.33271315 & 49.176 & 54 & 6 & 115.548 & 0 & 3 & 2006 \\
\hline COAL 3 & 38,616 & $10,524.345$ & 48.4041197 & 46.1896 & 40 & 8 & 113.913 & 0 & 3 & 2007 \\
\hline COAL 4 & $66,516.06$ & $13,065.5$ & 8374.268814 & 34.0332 & 34 & 6 & 115.848 & 0 & 3 & 2008 \\
\hline COAL 5 & $49,814.64$ & $12,482.7341$ & 34.77017608 & 31.9186 & 41 & 8 & 123.858 & 1 & 3 & 2009 \\
\hline COAL 6 & 101,367 & 2500.169 & 36.35576945 & 41.2271 & 51 & 12 & 140.973 & 1 & 3 & 2010 \\
\hline COAL 7 & $160,159.86$ & 2562.054 & 173.0073569 & 65.3027 & 55 & 13 & 166.284 & 1 & 3 & 2011 \\
\hline COAL 8 & $373,609.8$ & 1593.613 & 47.0007861 & 53.1 & 60 & 15 & 151.965 & 1 & 3 & 2012 \\
\hline COAL 9 & $385,677.3$ & 2976.138 & 34.43243626 & 62.8539 & 58 & 15.7 & 153.78 & 1 & 3 & 2013 \\
\hline COAL 10 & 386,160 & 6353.802 & 0.271669292 & 63.2565 & 60 & 16.9 & 135.087 & 1 & 3 & 2014 \\
\hline
\end{tabular}




\section{Continued}

\begin{tabular}{|c|c|c|c|c|c|c|c|c|c|c|}
\hline Cobalt 1 & $127,104.564$ & 398.3646084 & $10,327.11593$ & 56.7266 & 56 & 4 & 2046.793422 & 0 & 4 & 2005 \\
\hline Cobalt 2 & $1,501,879.216$ & 307.99 & 9290.76148 & 49.176 & 54 & 6 & 1748.6264 & 0 & 4 & 2006 \\
\hline Cobalt 3 & $584,388.8$ & 208.9 & $14,639.83018$ & 46.1896 & 40 & 8 & 1723.8834 & 0 & 4 & 2007 \\
\hline Cobalt 4 & $1,006,609.708$ & 253.99 & 14009 & 34.0332 & 34 & 6 & 1753.1664 & 0 & 4 & 2008 \\
\hline Cobalt 5 & $753,861.552$ & 39.001 & $12,145.61165$ & 31.9186 & 41 & 8 & 1874.3844 & 1 & 4 & 2009 \\
\hline Cobalt 6 & $1,534,020.6$ & 57.619 & $11,888.56388$ & 41.2271 & 51 & 12 & 2133.3914 & 1 & 4 & 2010 \\
\hline Cobalt 7 & $2,423,752.548$ & 173.976 & 9569.47364 & 65.3027 & 55 & 13 & 2516.4312 & 1 & 4 & 2011 \\
\hline Cobalt 8 & $5,653,961.64$ & 194.517 & 14.535 .61711 & 53.1 & 60 & 15 & 2299.737 & 1 & 4 & 2012 \\
\hline Cobalt 9 & $5,836,583.14$ & 318.924 & $10,910.43911$ & 62.8539 & 58 & 15.7 & 2327.204 & 1 & 4 & 2013 \\
\hline Cobalt 10 & $5,843,888$ & 357.808 & $1.51899 \mathrm{E}-06$ & 63.2565 & 60 & 16.9 & 2044.3166 & 1 & 4 & 2014 \\
\hline Copper 1 & $59,632.758$ & $12,949.27753$ & 8226.788825 & 56.7266 & 56 & 4 & 960.2797333 & 0 & 5 & 2005 \\
\hline Copper 2 & $704,626.152$ & 9619.8371 & 4006.955799 & 49.176 & 54 & 6 & 820.3908 & 0 & 5 & 2006 \\
\hline Copper 3 & $274,173.6$ & $10,137.4813$ & 3893.484296 & 46.1896 & 40 & 8 & 808.7823 & 0 & 5 & 2007 \\
\hline Copper 4 & $472,264.026$ & 1011.653 & 2366.4 & 34.0332 & 34 & 6 & 822.5208 & 0 & 5 & 2008 \\
\hline Copper 5 & $353,683.944$ & 3571.84 & 4314.997592 & 31.9186 & 41 & 8 & 879.3918 & 1 & 5 & 2009 \\
\hline Copper 6 & $719,705.7$ & 4629.03 & 6159.438586 & 41.2271 & 51 & 12 & 1000.9083 & 1 & 5 & 2010 \\
\hline Copper 7 & $1,137,135.006$ & 6554.601 & 6079.88436 & 65.3027 & 55 & 13 & 1180.6164 & 1 & 5 & 2011 \\
\hline Copper 8 & $2,652,629.58$ & 6665.27 & 5880.228834 & 53.1 & 60 & 15 & 1078.9515 & 1 & 5 & 2012 \\
\hline Copper 9 & $2,738,308.83$ & 8284.557 & 5344.367934 & 62.8539 & 58 & 15.7 & 1091.838 & 1 & 5 & 2013 \\
\hline Copper 10 & $2,741,736$ & 8261.419 & $9.67245 \mathrm{E}-07$ & 63.2565 & 60 & 16.9 & 959.1177 & 1 & 5 & 2014 \\
\hline Gold 1 & $563,683.5444$ & 14,203 & $35,480.78955$ & 56.7266 & 56 & 4 & 9077.123076 & 0 & 6 & 2005 \\
\hline Gold 2 & $6,660,536.594$ & 11,354 & $18,934.37719$ & 49.176 & 54 & 6 & 7754.81144 & 0 & 6 & 2006 \\
\hline Gold 3 & $2,591,648.48$ & 7018 & $72,636.91313$ & 46.1896 & 40 & 8 & 7645.08114 & 0 & 6 & 2007 \\
\hline Gold 4 & $4,464,114.507$ & 3579 & 9233.39877 & 34.0332 & 34 & 6 & 7774.94544 & 0 & 6 & 2008 \\
\hline Gold 5 & $3,343,226.539$ & 4965.7449 & $31,652.9657$ & 31.9186 & 41 & 8 & 8312.52324 & 1 & 6 & 2009 \\
\hline Gold 6 & $6,803,077.26$ & 9619.8371 & $39,547.23107$ & 41.2271 & 51 & 12 & 9461.16794 & 1 & 6 & 2010 \\
\hline Gold 7 & $10,748,862.07$ & $12,949.27753$ & $26,051.51405$ & 65.3027 & 55 & 13 & $11,159.8735$ & 1 & 6 & 2011 \\
\hline Gold 8 & $25,074,199.04$ & 0 & $53,093.13125$ & 53.1 & 60 & 15 & $10,198.8777$ & 1 & 6 & 2012 \\
\hline Gold 9 & $25,884,089.19$ & $14,001.3241$ & 44515.10292 & 62.8539 & 58 & 15.7 & $10,320.6884$ & 1 & 6 & 2013 \\
\hline Gold 10 & $25,916,484.8$ & $15,385.7389$ & 2.038005589 & 63.2565 & 60 & 16.9 & 9066.13886 & 1 & 6 & 2014 \\
\hline GRAPH 1 & $89,869.086$ & 3456 & 275.8747397 & 56.7266 & 56 & 4 & 1447.182133 & 0 & 7 & 2005 \\
\hline GRAPH 2 & $1,061,901.384$ & 3567 & 114.032357 & 49.176 & 54 & 6 & 1236.3636 & 0 & 7 & 2006 \\
\hline GRAPH 3 & $413,191.2$ & 3907 & 162.8050178 & 46.1896 & 40 & 8 & 1218.8691 & 0 & 7 & 2007 \\
\hline GRAPH 4 & $711,721.842$ & 1976 & 2149.42 & 34.0332 & 34 & 6 & 1239.5736 & 0 & 7 & 2008 \\
\hline GRAPH 5 & $533,016.648$ & 2463 & 291.7966995 & 31.9186 & 41 & 8 & 1325.2806 & 1 & 7 & 2009 \\
\hline GRAPH 6 & $1,084,626.9$ & 741 & 366.9271255 & 41.2271 & 51 & 12 & 1508.4111 & 1 & 7 & 2010 \\
\hline GRAPH 7 & $1,713,710.502$ & 7252 & 494.9819 & 65.3027 & 55 & 13 & 1779.2388 & 1 & 7 & 2011 \\
\hline
\end{tabular}


Continued

\begin{tabular}{|c|c|c|c|c|c|c|c|c|c|c|}
\hline GRAPH 8 & $3,997,624.86$ & 7022 & 576.5069781 & 53.1 & 60 & 15 & 1626.0255 & 1 & 7 & 2012 \\
\hline GRAPH 9 & $4,126,747.11$ & 6934 & 537.5506201 & 62.8539 & 58 & 15.7 & 1645.446 & 1 & 7 & 2013 \\
\hline GRAPH 10 & $4,131,912$ & 6853 & $4.37076 \mathrm{E}-08$ & 63.2565 & 60 & 16.9 & 1445.4309 & 1 & 7 & 2014 \\
\hline IRID 1 & $34,435.818$ & 657.678 & 7858.224499 & 56.7266 & 56 & 4 & 554.5277333 & 0 & 8 & 2005 \\
\hline IRID 2 & $406,896.792$ & 687.906 & 4229.461417 & 49.176 & 54 & 6 & 473.7468 & 0 & 8 & 2006 \\
\hline IRID 3 & $158,325.6$ & 456.8705 & 4130.281552 & 46.1896 & 40 & 8 & 467.0433 & 0 & 8 & 2007 \\
\hline IRID 4 & $272,715.846$ & 198.9782 & 4790.1 & 34.0332 & 34 & 6 & 474.9768 & 0 & 8 & 2008 \\
\hline IRID 5 & $204,240.024$ & 208.9 & 6999.147918 & 31.9186 & 41 & 8 & 507.8178 & 1 & 8 & 2009 \\
\hline IRID 6 & $415,604.7$ & 253.99 & $10,406.06323$ & 41.2271 & 51 & 12 & 577.9893 & 1 & 8 & 2010 \\
\hline IRID 7 & $656,655.426$ & 398.3646084 & $11,597.8474$ & 65.3027 & 55 & 13 & 681.7644 & 1 & 8 & 2011 \\
\hline IRID 8 & $1,531,800.18$ & 412.014 & $21,823.51593$ & 53.1 & 60 & 15 & 623.0565 & 1 & 8 & 2012 \\
\hline IRID 9 & $1,581,276.93$ & 519.604 & $15,721.36884$ & 62.8539 & 58 & 15.7 & 630.498 & 1 & 8 & 2013 \\
\hline IRID 10 & $1,583,256$ & 544.3882 & $1.88177 \mathrm{E}-06$ & 63.2565 & 60 & 16.9 & 553.8567 & 1 & 8 & 2014 \\
\hline NICK 1 & $59,632.758$ & $20,789.809$ & $28,258.23462$ & 56.7266 & 56 & 4 & 960.2797333 & 0 & 9 & 2005 \\
\hline NICK 2 & $704,626.152$ & $21,677.097$ & $16,234.58643$ & 49.176 & 54 & 6 & 820.3908 & 0 & 9 & 2006 \\
\hline NICK 3 & $274,173.6$ & $13,456.5047$ & $19,105.24519$ & 46.1896 & 40 & 8 & 808.7823 & 0 & 9 & 2007 \\
\hline NICK 4 & $472,264.026$ & 3056.308 & 15239.7 & 34.0332 & 34 & 6 & 822.5208 & 0 & 9 & 2008 \\
\hline NICK 5 & $353,683.944$ & 4857.528 & $12,805.68738$ & 31.9186 & 41 & 8 & 879.3918 & 1 & 9 & 2009 \\
\hline NICK 6 & $719,705.7$ & 6133.483 & $18,132.66296$ & 41.2271 & 51 & 12 & 1000.9083 & 1 & 9 & 2010 \\
\hline NICK 7 & $1,137,135.006$ & 7992.188 & $24,748.64246$ & 65.3027 & 55 & 13 & 1180.6164 & 1 & 9 & 2011 \\
\hline NICK 8 & $2,652,629.58$ & 7898.719 & $14,225.21917$ & 53.1 & 60 & 15 & 1078.9515 & 1 & 9 & 2012 \\
\hline NICK 9 & $2,738,308.83$ & $12,961.947$ & $11,243.47113$ & 62.8539 & 58 & 15.7 & 1091.838 & 1 & 9 & 2013 \\
\hline NICK 10 & $2,741,736$ & $16,632.728$ & $5.74789 \mathrm{E}-06$ & 63.2565 & 60 & 16.9 & 959.1177 & 1 & 9 & 2014 \\
\hline PALA 1 & $95,468.406$ & $11,344.89$ & $15,030.36097$ & 56.7266 & 56 & 4 & 1537.349244 & 0 & 10 & 2005 \\
\hline PALA 2 & $1,128,063.464$ & 9876.078 & 6227.088127 & 49.176 & 54 & 6 & 1313.3956 & 0 & 10 & 2006 \\
\hline PALA 3 & $438,935.2$ & 7789.305 & 5982.152927 & 46.1896 & 40 & 8 & 1294.8111 & 0 & 10 & 2007 \\
\hline PALA 4 & $756,065.882$ & 4678.7098 & 3585.4 & 34.0332 & 34 & 6 & 1316.8056 & 0 & 10 & 2008 \\
\hline PALA 5 & $566,226.408$ & 5354.449 & 7692.078867 & 31.9186 & 41 & 8 & 1407.8526 & 1 & 10 & 2009 \\
\hline PALA 6 & $1,152,204.9$ & 6916.102 & $14,553.65305$ & 41.2271 & 51 & 12 & 1602.3931 & 1 & 10 & 2010 \\
\hline PALA 7 & $1,820,483.742$ & 8421.674655 & $15,993.65023$ & 65.3027 & 55 & 13 & 1890.0948 & 1 & 10 & 2011 \\
\hline PALA 8 & $4,246,698.06$ & 8136.213 & $18,266.87147$ & 53.1 & 60 & 15 & 1727.3355 & 1 & 10 & 2012 \\
\hline PALA 9 & $4,383,865.31$ & 9642.575 & $20,269.37736$ & 62.8539 & 58 & 15.7 & 1747.966 & 1 & 10 & 2013 \\
\hline PALA 10 & $4,389,352$ & $10,137.4813$ & $3.0478 \mathrm{E}-06$ & 63.2565 & 60 & 16.9 & 1535.4889 & 1 & 10 & 2014 \\
\hline PHOS 1 & $504,294.3568$ & 194.517 & 102.7599696 & 56.7266 & 56 & 4 & 94.67546667 & 0 & 11 & 2005 \\
\hline PHOS 2 & $5,958,788.492$ & 173.976 & 44.63377392 & 49.176 & 54 & 6 & 80.8836 & 0 & 11 & 2006 \\
\hline PHOS 3 & $2,318,594.744$ & 39.001 & 47.92290091 & 46.1896 & 40 & 8 & 79.7391 & 0 & 11 & 2007 \\
\hline PHOS 4 & $3,993,779.447$ & 0 & $48,679.6824$ & 34.0332 & 34 & 6 & 81.0936 & 0 & 11 & 2008 \\
\hline
\end{tabular}


Continued

\begin{tabular}{|c|c|c|c|c|c|c|c|c|c|c|}
\hline PHOS 5 & $2,990,987.22$ & 0 & 0 & 31.9186 & 41 & 8 & 86.7006 & 1 & 11 & 2009 \\
\hline PHOS 6 & $6,086,311.203$ & 56.656 & 104.7510265 & 41.2271 & 51 & 12 & 98.6811 & 1 & 11 & 2010 \\
\hline PHOS 7 & $9,616,371.701$ & 46.047 & 1015.791646 & 65.3027 & 55 & 13 & 116.3988 & 1 & 11 & 2011 \\
\hline PHOS 8 & $22,432,404.15$ & 16.79 & 101.4549796 & 53.1 & 60 & 15 & 106.3755 & 1 & 11 & 2012 \\
\hline PHOS 9 & $23,156,965.01$ & 0 & 61.36901639 & 62.8539 & 58 & 15.7 & 107.646 & 1 & 11 & 2013 \\
\hline PHOS 10 & $23,185,947.44$ & 0 & 0.099877746 & 63.2565 & 60 & 16.9 & 94.5609 & 1 & 11 & 2014 \\
\hline PLATI 1 & $504,294.3568$ & $599,079.38$ & $68,017.15464$ & 56.7266 & 56 & 4 & 8120.765612 & 0 & 12 & 2005 \\
\hline PLATI 2 & $5,958,788.492$ & $408,475.81$ & $22,659.70376$ & 49.176 & 54 & 6 & 6937.771532 & 0 & 12 & 2006 \\
\hline PLATI 3 & $2,318,594.744$ & 355142 & $23,390.33738$ & 46.1896 & 40 & 8 & 6839.602317 & 0 & 12 & 2007 \\
\hline PLATI 4 & $3,993,779.447$ & 408,422 & 19,273 & 34.0332 & 34 & 6 & 6955.78423 & 0 & 12 & 2008 \\
\hline PLATI 5 & $2,990,987.22$ & 6848.899 & $34,909.14657$ & 31.9186 & 41 & 8 & 7436.72332 & 1 & 12 & 2009 \\
\hline PLATI 6 & $6,086,311.203$ & 8638.65 & $47,352.96395$ & 41.2271 & 51 & 12 & 8464.34786 & 1 & 12 & 2010 \\
\hline PLATI 7 & $9,616,371.701$ & $10,826.55914$ & $39,646.1825$ & 65.3027 & 55 & 13 & 9984.07936 & 1 & 12 & 2011 \\
\hline PLATI 8 & $22,432,404.15$ & $10,524.345$ & $44,137.99721$ & 53.1 & 60 & 15 & 9124.33319 & 1 & 12 & 2012 \\
\hline PLATI 9 & $23,156,965.01$ & $13,065.5$ & 42401.77305 & 62.8539 & 58 & 15.7 & 9233.31002 & 1 & 12 & 2013 \\
\hline PLATI 10 & $23,185,947.44$ & $12,482.7341$ & $1.1133 \mathrm{E}-06$ & 63.2565 & 60 & 16.9 & 8110.93868 & 1 & 12 & 2014 \\
\hline RHOD 1 & $78,026.5242$ & 1319.9 & $140,644.356$ & 56.7266 & 56 & 4 & 1256.478693 & 0 & 13 & 2005 \\
\hline RHOD 2 & $921,968.5848$ & 1416.1 & $86,500.98391$ & 49.176 & 54 & 6 & 1073.44092 & 0 & 13 & 2006 \\
\hline RHOD 3 & $358,742.64$ & 1256.8 & $101,595.3962$ & 46.1896 & 40 & 8 & 1058.25177 & 0 & 13 & 2007 \\
\hline RHOD 4 & $617,934.1974$ & 509.7 & 285936 & 34.0332 & 34 & 6 & 1076.22792 & 0 & 13 & 2008 \\
\hline RHOD 5 & $462,778.0056$ & 568.132 & $42,339.41232$ & 31.9186 & 41 & 8 & 1150.64082 & 1 & 13 & 2009 \\
\hline RHOD 6 & $941,699.43$ & 726.904 & $69,156.03023$ & 41.2271 & 51 & 12 & 1309.63917 & 1 & 13 & 2010 \\
\hline RHOD 7 & $1,487,885.099$ & 940.3199851 & $28,147.77106$ & 65.3027 & 55 & 13 & 1544.77836 & 1 & 13 & 2011 \\
\hline RHOD 8 & $3,470,835.042$ & 890.676 & $35,053.14655$ & 53.1 & 60 & 15 & 1411.75485 & 1 & 13 & 2012 \\
\hline RHOD 9 & $3,582,942.117$ & 1146.089 & $28,697.87756$ & 62.8539 & 58 & 15.7 & 1428.6162 & 1 & 13 & 2013 \\
\hline RHOD 10 & $3,587,426.4$ & 1139.9235 & $1.24546 \mathrm{E}-05$ & 63.2565 & 60 & 16.9 & 1254.95823 & 1 & 13 & 2014 \\
\hline RHUT 1 & $27,324.6816$ & 1345.089 & 3839.079037 & 56.7266 & 56 & 4 & 440.0155022 & 0 & 14 & 2005 \\
\hline RHUT 2 & $322,870.9504$ & 1045.983 & 2624.86715 & 49.176 & 54 & 6 & 375.91616 & 0 & 14 & 2006 \\
\hline RHUT 3 & $125,630.72$ & 967.5804 & 5131.06564 & 46.1896 & 40 & 8 & 370.59696 & 0 & 14 & 2007 \\
\hline RHUT 4 & $216,398.9152$ & 300.987 & 1639.8 & 34.0332 & 34 & 6 & 376.89216 & 0 & 14 & 2008 \\
\hline RHUT 5 & $162,063.6288$ & 412.777 & 1723.90419 & 31.9186 & 41 & 8 & 402.95136 & 1 & 14 & 2009 \\
\hline RHUT 6 & $329,780.64$ & 555.021 & 3637.410116 & 41.2271 & 51 & 12 & 458.63216 & 1 & 14 & 2010 \\
\hline RHUT 7 & $521,053.4112$ & 823.0314914 & 3194.90559 & 65.3027 & 55 & 13 & 540.97728 & 1 & 14 & 2011 \\
\hline RHUT 8 & $1,215,477.216$ & 787.169 & 2225.389544 & 53.1 & 60 & 15 & 494.3928 & 1 & 14 & 2012 \\
\hline RHUT 9 & $1,254,736.816$ & 1011.653 & 1509.744593 & 62.8539 & 58 & 15.7 & 500.2976 & 1 & 14 & 2013 \\
\hline RHUT 10 & $1,256,307.2$ & 982.5804 & $6.96598 \mathrm{E}-07$ & 63.2565 & 60 & 16.9 & 439.48304 & 1 & 14 & 2014 \\
\hline
\end{tabular}




\section{Appendix 2: Summary Statistics}

Table A2. Summary statistics.

\begin{tabular}{|c|c|c|c|c|}
\hline Variable & Mean & Median & Minimum & Maximum \\
\hline fdi & $3.6338 \mathrm{e}+006$ & $1.2555 \mathrm{e}+006$ & 8399.0 & $2.5916 \mathrm{e}+007$ \\
\hline out & 34637. & 3511.5 & 0.00000 & $5.9908 \mathrm{e}+005$ \\
\hline price & 14964. & 4179.9 & 0.00000 & $2.8594 \mathrm{e}+005$ \\
\hline vmi & 50.380 & 51.150 & 31.900 & 65.300 \\
\hline $\mathrm{cu}$ & 50.900 & 54.500 & 34.000 & 60.000 \\
\hline contr & 10.460 & 10.000 & 4.0000 & 16.900 \\
\hline labr & 2370.4 & 1302.5 & 80.000 & 11160. \\
\hline ps & 0.60000 & 1.0000 & 0.00000 & 1.0000 \\
\hline Variable & Std. Dev. & C.V. & Skewness & Ex. kurtosis \\
\hline fdi & $5.9342 \mathrm{e}+006$ & 1.6331 & 2.6143 & 6.1548 \\
\hline out & $1.1316 \mathrm{e}+005$ & 3.2671 & 3.7207 & 12.776 \\
\hline price & 31417. & 2.0995 & 5.4647 & 39.860 \\
\hline vmi & 11.472 & 0.22770 & -0.25720 & -1.2446 \\
\hline $\mathrm{cu}$ & 8.8116 & 0.17312 & -0.73808 & -0.93698 \\
\hline contr & 4.3973 & 0.42039 & 0.056813 & -1.4936 \\
\hline labr & 2803.9 & 1.1829 & 1.6481 & 1.4880 \\
\hline ps & 0.49166 & 0.81943 & -0.40825 & -1.8333 \\
\hline Variable & 5\% Perc. & 95\% Perc. & IQ range & Missing obs. \\
\hline fdi & 59977. & $2.3121 \mathrm{e}+007$ & $3.5829 e+006$ & 0 \\
\hline out & 0.00000 & $4.0576 \mathrm{e}+005$ & 9149.7 & 0 \\
\hline price & 0.00000 & 67271. & 16049. & 0 \\
\hline vmi & 31.900 & 65.300 & 21.700 & 0 \\
\hline $\mathrm{cu}$ & 34.000 & 60.000 & 17.000 & 0 \\
\hline contr & 4.0000 & 16.900 & 9.0000 & 0 \\
\hline labr & 99.350 & 9121.6 & 1766.0 & 0 \\
\hline ps & 0.00000 & 1.0000 & 1.0000 & 0 \\
\hline
\end{tabular}




\section{Appendix 3: Correlation Matrix}

Table A3. Correlation coefficients, using the observations 1:01 - 14:10. 5\% critical value (two-tailed $)=0.1660$ for $\mathrm{n}=140$.

\begin{tabular}{cccccc}
\hline out & price & vmi & cu & contr & labr \\
\hline 1.0000 & 0.0059 & 0.0437 & 0.0357 & -0.0027 & 0.3477 \\
& 1.0000 & -0.1119 & -0.1358 & -0.1561 & 0.2088 \\
& & 1.0000 & 0.8224 & 0.5554 & 0.0728 \\
& & 1.0000 & 0.5913 & 0.0730 \\
& & & 1.0000 & 0.0736 \\
& & & & & 1.0000
\end{tabular}

\section{Appendix 4}

Table A4. Model 1: Random-effects (GLS), using 140 observations; Included 14 cross-sectional units; Time-series length $=10$; Dependent variable: 1 ffdi.

(a)

\begin{tabular}{cccccc}
\hline & Coefficient & Std. Error & $Z$ & $p$-value & \\
\hline const & 8.25078 & 0.746805 & 11.05 & $<0.0001$ & $* * *$ \\
ps & -1.03696 & 0.395350 & -2.623 & 0.0087 & $* * *$ \\
1_labr & 0.510446 & 0.0717979 & 7.109 & $<0.0001$ & $* * *$ \\
vmi & -0.0393250 & 0.0166948 & -2.356 & 0.0185 & $* *$ \\
cu & 0.0207884 & 0.0205690 & 1.011 & 0.3122 & \\
contr & 0.352366 & 0.0483561 & 7.287 & $<0.0001$ & $* * *$ \\
\hline
\end{tabular}

(b)

\begin{tabular}{cccc}
\hline Mean dependent var & 14.00240 & S.D. dependent var & 1.643830 \\
\hline Sum squared resid & 159.6645 & S.E. of regression & 1.087520 \\
Log-likelihood & -207.8516 & Akaike criterion & 427.7033 \\
Schwarz criterion & 445.3531 & Hannan-Quinn & 434.8756 \\
\hline
\end{tabular}

'Between' variance $=0$

'Within' variance $=1.25397$

theta used for quasi-demeaning $=0$

Joint test on named regressors-

Asymptotic test statistic: Chi-square(5) = 181.228

with p-value $=2.92486 \mathrm{e}-037$

Breusch-Pagan test-

ull hypothesis: Variance of the unit-specific error $=0$

symptotic test statistic: Chi-square $(1)=3.70976$

ith $\mathrm{p}$-value $=0.0540952$

Hausman test-

Null hypothesis: GLS estimates are consistent

Asymptotic test statistic: Chi-square $(5)=4.24038$

with $\mathrm{p}$-value $=0.515352$ 